\title{
Analysis of nonsuicidal self-injury posts on Twitter: A quantitative and qualitative
}

\section{research}

\author{
Análise de postagens sobre autolesão não suicida no Twitter: Um estudlo misto \\ Análisis de publicaciones de autolesiones no suicida en Twitter: Una investigación cuantitativa y \\ cualitativa
}

Received: 02/16/2021 | Reviewed: 02/21/2021 |Accept: 04/06/2021 | Published: 04/16/2021

\author{
Aline Conceição Silva \\ ORCID: https://orcid.org/0000-0001-5843-2517 \\ University of São Paulo, Brazil \\ E-mail: csilvaaline@hotmail.com \\ Kelly Graziani Giacchero Vedana \\ ORCID: https://orcid.org/0000-0001-7363-2429 \\ University of São Paulo, Brazil \\ E-mail: kellygiacchero@eerp.usp.br \\ José Carlos Pereira dos Santos \\ ORCID: https://orcid.org/0000-0003-1574-972X \\ Coimbra Nursing Higher School, Portugal \\ E-mail: jcsantos@esenfc.pt \\ Sandra Cristina Pillon \\ ORCID: https://orcid.org/0000-0001-8902-7549 \\ University of São Paulo, Brazil \\ E-mail: pillon@eerp.usp.br \\ Carla Aparecida Arena Ventura \\ ORCID: https://orcid.org/0000-0003-0379-913X \\ University of São Paulo, Brazil \\ E-mail: caaventu@eerp.usp.br \\ Adriana Inocenti Miasso \\ ORCID: https://orcid.org/0000-0003-1726-7169 \\ University of São Paulo, Brazil \\ E-mail: amiasso@eerp.usp.br
}

\begin{abstract}
Retrospective study, of mixed approach, with quantitative and qualitative approaches, with the objective of analyzing posts about non-suicidal self-harm on Twitter. The posts were collected through screen capture, transcribed and encoded. Quantitative data were analyzed using descriptive statistics, association tests and multiple logistic regression, with a significance level of 5\%. Qualitative data were analyzed using thematic analysis by Braun and Clarke. In the results, female profile tweets and potentially harmful content prevailed. The expression of the suicidal behavior of the author of the post was associated with the encouragement of non-suicidal self-harm and increased chances of sharing and commenting on the posts. Reply posts were more likely to receive likes and comments. Posts encouraging non-suicidal self-harm describe social manifestations of behavior and exposure to non-suicidal self-harm through mass communication. The results bring important discussions about the potential impact of posts on nonsuicidal self-harm and reflection on the discussion of behavior in the digital social context. It is important that mental health actions include tracking risk behaviors on the internet, supporting people in situations of vulnerability, redirecting to support services, as well as strategic actions to promote the conscious and healthy use of social networks.
\end{abstract}

Keywords: Self-injurious behavior; Internet; Mental health.

\section{Resumo}

Estudo retrospectivo, de abordagem mista, com abordagens quantitativa e qualitativa, com objetivo de analisar postagens sobre autolesão não suicida no Twitter. As postagens foram coletadas por meio de captura de tela, transcritas e codificadas. Os dados quantitativos foram analisados por meio de estatística descritiva, testes de associação e regressão logística múltipla, adotado nível de significância de 5\%. Os dados qualitativos foram analisados por meio da Análise Temática de Braun e Clarke. Nos resultados prevaleceram os tweets de perfis femininos e conteúdos potencialmente prejudiciais. A expressão do comportamento suicida do autor da postagem foi associada ao incentivo de autolesão não suicida e aumento das chances de compartilhar e comentar as postagens. Postagens de resposta tinham maior probabilidade de receber curtidas e comentários. As postagens encorajando a 
autolesão não suicida descrevem manifestações sociais ao comportamento e exposição a autolesão não suicida por meio da comunicação em massa. Os resultados trazem importantes discussões sobre o potencial do impacto de postagens sobre autolesão não suicida e reflexão sobre a discussão do comportamento no contexto social digital. É importante que as ações em saúde mental incluam o rastreamento de comportamentos de risco na internet, apoio a pessoas em situação de vulnerabilidade, redirecionamento para serviços de apoio, além de ações estratégicas para promover o uso consciente e saudável das redes sociais.

Palavras-chave: Comportamento autodestrutivo; Internet; Saúde mental.

\section{Resumen}

Estudio retrospectivo, de abordaje mixto, con abordajes cuantitativos y cualitativos, con el objetivo de analizar publicaciones sobre autolesiones no suicidas en Twitter. Las publicaciones fueron recopiladas mediante captura de pantalla, transcritas y codificadas. Los datos cuantitativos se analizaron mediante estadística descriptiva, pruebas de asociación y regresión logística múltiple, con un nivel de significancia del 5\%. Los datos cualitativos se analizaron mediante análisis temático de Braun y Clarke. En los resultados prevalecieron los tweets de perfil femenino y el contenido potencialmente dañino. La expresión del comportamiento suicida del autor de la publicación se asoció con el fomento de la autolesión no suicida y el aumento de las posibilidades de compartir y comentar las publicaciones. Las publicaciones de respuesta tenían más probabilidades de recibir me gusta y comentarios. Las publicaciones que fomentan la autolesión no suicida describen las manifestaciones sociales de la conducta y la exposición a autolesiones no suicidas a través de la comunicación masiva. Los resultados traen importantes discusiones sobre el impacto potencial de las publicaciones en las autolesiones no suicidas y la reflexión sobre la discusión del comportamiento en el contexto social digital. Es importante que las acciones de salud mental incluyan el seguimiento de conductas de riesgo en internet, el apoyo a personas en situación de vulnerabilidad, la redirección a servicios de apoyo, así como acciones estratégicas para promover el uso consciente y saludable de las redes sociales.

Palabras clave: Conducta autodestructiva; Internet; Salud mental.

\section{Introduction}

Nonsuicidal self-injury (NSSI) represents an intentional self-inflicted damage to the surface of the body with the expectation that the injury will result in minor or moderate physical damage, thus, without suicidal intentionality. NSSI associates with non-adaptive or ineffective coping mechanisms for solving problems and seeking relief from negative feelings or cognitions, solving interpersonal problems, and inducing positive feelings. Transient relief is usually experienced during or after NSSI and the individual can intensify engagement in the behavior resulting in dependency (American Psychiatric Association, 2013), shame-related sufferings, impairments in social relationships and self-perception. Furthermore, NSSI is a risk factor for future suicide(American Psychiatric Association, 2013; Lim et al., 2019).

Communication on NSSI on the Internet has increased in the last years, and the type of contents available for users and their repercussion in the daily life of these individuals is worrying (Lewis, Heath, Michal, \& Duggan, 2012; Marchant et al., 2017; Cassel; Terribile; Machado, 2019). A review study identified that the Internet could catalyze a support network for people with NSSI, but it also promotes access to NSSI media, content that normalizes this behavior, violent content, intimidation or harassment of vulnerable people (Moreno et al., 2016).

On Twitter, content on platform-aware use, content reporting tools, and redirection to support services are available, although there is no control over posts. Exposure to NSSI methods, encouragement or enhancement of suicidal behavior may favor the contagion effect among vulnerable people (Vedana, Silva, et al., 2018). Therefore, it is important to understand the characteristics and contents of posts on NSSI and suicidal behavior, as well as the involvement and interest that they created to strengthen research in the mental health area, as well as to subsidize prevention and care actions (Vedana, Donato, et al., 2018; Vedana, Pereira, Di Donato, \& Vanzela, 2018).

Understanding the phenomenon in an online environment and its repercussions is a challenge and a need. It is important that research is carried out with the purpose of learning about the real and virtual life relationship and the impacts on the health of the population. Caregivers should also be encouraged to question and understand the patient's history of interaction or preferences as well as to support tools and guidance recommendations (Lewis et al., 2012). 
Thus, the present study aimed to analyze posts about NSSI on Twitter. We expected improve the knowledge about the virtual content and involvement related to NSSI in order to subsidize the preventive and care planning.

\section{Methodology}

\subsection{Study Type}

Retrospective study, of mixed approach that uses the quantitative and qualitative approaches, articulates different sources of evidence, addressing a greater variety of elements. The concurrent strategy was used, which allows simultaneous data collection but independently (Pereira et. al, 2018).

\subsection{Scenario}

Twitter, a virtual social network in activity since 2006, enables interaction between users mainly by tweets, brief texts with a maximum of 280 characters. According to the social network itself, Twitter is characterized as the best place to know about current affairs and what people are talking about. A tweet is an opinion expression tool that starts from a point of view and user experience or livingness. Thus, it is perceived the recognition of the power of scientific research from virtual social networks to know social perceptions about certain subjects and the need to transform this knowledge into something possible for health care desired.

\subsection{Post search strategy}

The research was conducted in Twitter's advanced search tool using the term "self-mutilation" and application of search filters in the "Portuguese" language, referring to the period of "September 2016 to August 2017" and publications with public visualization, that is, visible independent of Twitter login and user authorization.

\subsection{Inclusion and exclusion criteria}

Were collected 6,302 using the search strategy mentioned above. For this study, we opted for the quantitative analysis of the total number of posts collected (6,302 posts) and for qualitative analysis the posts that presented directly or indirectly non-suicidal self-injury (663 posts). All posts were public (free access and no login required for viewing), in Portuguese and published from September 2016 to August 2017. The contents of videos, links, audios, chats and images were excluded.

\subsection{Data collection}

Posts were saved through screenshot and identified by month and by a number corresponding to the order in which it was found. Each post was transcribed in editable document and transcripts went through the review process for correcting possible errors. Identifications of profiles, people and institutions were removed to safeguard anonymity, being replaced in the posts by explanation between keys.

\subsection{Treatment and Analysis of Quantitative Data}

After extracting the data, in order to organize the material obtained, a database was built in Microsoft Excel 2010. The characteristics of the posts were coded according to a form prepared by experts. The following variables were considered: sex of the author (female, male, or inconclusive, when it was not possible to identify the sex of the author), type of post: tweet, (publication produced by the author), retweet (sharing of a post) or reply (reply to a previous post); number of likes; number of shares; number of comments; post portrays first-person (yes or no); encouraging nonsuicidal self-injury (yes or no); expression 
of the need for specialized treatment or follow-up (yes or no), mention the nonsuicidal self-injury method (yes or no) and expression of their suicidal behavior by ideation, plan or suicide attempt (yes or no).

Data were double-typed to avoid possible errors, as well as the crossing between the first and second typing to analyze the consistency and veracity of the data obtained. Subsequently, they were exported to the statistical program SAS (Statistical Analysis System) version 9.2 and analyzed statistically. Data were analyzed by descriptive statistics and later submitted to association tests between the variables of interest and multiple logistic regression model, with the dichotomization of variables as the best way to evaluate them. For all tests, the level of significance was 5\%.

\subsection{Treatment and analysis of qualitative data}

The qualitative data were analyzed through Thematic Analysis, which can be used in different theoretical frameworks and seeks the identification of themes or patterns for the identification, analysis and communication of patterns and meanings extracted from the data examined. The data were analyzed by two researchers with experience in thematic analysis and nonsuicidal self-injury. Thematic Analysis was developed through the following phases: familiarization with data, construction of initial codes, search for themes, analysis of themes, definition and attribution of names to the themes and production of the report(Braun \& Clarke, 2006)

\subsection{Ethical aspects}

The study followed the recommendations of Resolution No. 466 of December 12, 2012, of the National Health Council and the Helsinki Declaration (Ministério da Saúde, 2012). The analyzed data is publicly accessible and is visible to any people who access the content. The anonymity of users was preserved at all stages of the research and consequent dissemination of results. The principles of autonomy, security, maximization of benefits and minimization of damages followed, in addition to justice, beneficence and protection.

\section{Results}

\subsection{Analysis of quantitative data}

The majority of posts on NSSI were tweets (79.6\%), of female profiles (68.8\%), written in second or third person (64.0\%). Most of the posts didn't have shares (82.2\%), likes (67.6\%) or comments (80.5\%). Most of the posts didn't have incentive to NSSI (89.4\%), they did not mention a method for NSSI practice (94.6\%), addressed NSSI as a condition requiring treatment (68.3\%) and they did not express an individual suicidal behavior (94.8\%) (Table 1). 
Table 1. Characterization of nonsuicidal self-injury posts $(n=6,302)$ on Twitter (2016-2017).

\begin{tabular}{lcc}
\hline \multicolumn{1}{c}{ Characteristics } & N & \% \\
\hline Gender & 3395 & 68.8 \\
Female & 1539 & 31.1 \\
Male & 1368 & \\
Inconclusive & & \\
Post type & 5019 & 79.6 \\
Tweet & 1100 & 17.4 \\
Reply & 183 & 2.9 \\
Retweet & & \\
First-person Speech & 2265 & 35.9 \\
Yes & 4037 & 64.0 \\
No & & \\
Belief about the need for treatment & 3388 & 68.3 \\
Yes & 1570 & 31.6 \\
No & 1344 & \\
Inconclusive & & 10.5 \\
Incentive to NSSI & 663 & 89.4 \\
Yes & 5639 & 5.3 \\
No & & 94.6 \\
Mentions NSSI Method & 337 & \\
Yes & 5965 & 5.1 \\
No & & 94.8 \\
Expresses individual suicidal behavior & 324 & 32.3 \\
Nos & 5978 & 67.6 \\
Like & & \\
Yes & 2036 & 17.7 \\
No & 4266 & 82.2 \\
Sharing & & 19.5 \\
Nes & 1121 & 80.5 \\
Comment & 5181 & \\
Yes & & \\
No & 1229 & \\
\hline
\end{tabular}

Source: Authors.

The postings of female profiles $(\mathrm{OR}=1.24 ; \mathrm{CI}=1.07-1.44 ; \mathrm{p}<0.01)$, without mentioning a suicidal behavior $(\mathrm{OR}=$ 1.47; $\mathrm{CI}=1.09-1.97 ; \mathrm{p}=0.01)$ and replies $(\mathrm{OR}=1.70 ; \mathrm{CI}=1.43-2.02 ; \mathrm{p}<0.01)$ had greater chances of receiving likes (Table 2). Posts from female profiles ( $\mathrm{OR}=1.24 ; \mathrm{CI}=1.04-1.49 ; \mathrm{p}=0.02)$, without a first-person speech $(\mathrm{OR}=1.36 ; \mathrm{CI}=1.39-2.04$; $\mathrm{p}<0.01)$, that addressed the treatment need for NSSI $(\mathrm{OR}=1.45 ; \mathrm{CI}=1.19-1.77 ; \mathrm{p}=0.01)$ or that expressed an individual suicidal behavior $(\mathrm{OR}=1.46 ; \mathrm{CI}=1.03-2.06 ; \mathrm{p}=0.03$ ) were more likely to be shared (Table 2$)$.

Reply posts $(\mathrm{OR}=8.75 ; \mathrm{CI}=7.22-10.61 ; \mathrm{p}<0.01)$ or retweets $(\mathrm{OR}=2.04 ; \mathrm{CI}=1.14-3.66 ; \mathrm{p}=0.02)$, with a firstperson speech $(\mathrm{OR}=1.68 ; \mathrm{CI}=1.39-2.02 ; \mathrm{p}<0.01)$ and that expressed a suicidal behavior $(\mathrm{OR}=1.59 ; \mathrm{CI}=1.10-2.28 ; \mathrm{p}=$ 0.01) had increased chances of being commented (Table 2). It should be noted that reply posts had almost nine times the chances of being commented when compared to tweets (Table 2:). 
Table 2. Interaction for likes, shares, and comments and other characteristics of nonsuicidal self-injury posts $(\mathrm{n}=6,302)$ on Twitter $(2016-2017)$.

\begin{tabular}{|c|c|c|c|c|c|c|c|c|c|}
\hline \multirow[b]{3}{*}{ Gender } & \multicolumn{3}{|c|}{ Likes } & \multicolumn{3}{|c|}{ Sharing } & \multicolumn{3}{|c|}{ Comments } \\
\hline & \multirow[t]{2}{*}{$\begin{array}{c}\text { Yes }(\mathbf{n}= \\
1255) \\
N(\%)\end{array}$} & \multirow[t]{2}{*}{ OR (CI) } & \multirow[t]{2}{*}{$\begin{array}{c}\text { P- } \\
\text { value }\end{array}$} & \multirow[t]{2}{*}{$\begin{array}{c}\text { Yes }(n=711) \\
N(\%)\end{array}$} & OR $(\mathrm{CI})$ & \multirow[t]{2}{*}{$\begin{array}{c}\text { P- } \\
\text { value }\end{array}$} & \multirow[t]{2}{*}{$\begin{array}{c}\text { Yes }(\mathbf{n}=708) \\
N(\%)\end{array}$} & OR $(\mathrm{CI})$ & \multirow[t]{2}{*}{$\begin{array}{c}\text { P- } \\
\text { value }\end{array}$} \\
\hline & & & & & & & & & \\
\hline Female & $907(33.3)$ & $1.24(1.07-1.44)$ & $<0.01$ & $514(18.9)$ & $1.24(1.04-1.49)$ & 0.02 & $515(18.9)$ & $1.22(0.99-1.49)$ & 0.06 \\
\hline Male & $348(28.6)$ & 1.00 & - & $197(16.2)$ & 1.00 & - & $193(15.8)$ & 1.00 & - \\
\hline \multicolumn{10}{|l|}{ Post type } \\
\hline Reply & $284(42.5)$ & $1.70(1.43-2.02)$ & $<0.01$ & $117(17.5)$ & $1.04(0.83-1.29)$ & 0.76 & $348(52.1)$ & $8.75(7.22-10.61)$ & $<0.01$ \\
\hline Retweet & $30(39.4)$ & $\begin{array}{c}1.53 \\
(0.96-2.44)\end{array}$ & 0.08 & $16(21.0)$ & $1.16(0.66-2.03)$ & 0.61 & 15 (19.7) & $2.04(1.14-3.66)$ & 0.02 \\
\hline \multicolumn{9}{|l|}{ First-person Speech } & - \\
\hline Yes & $460(34.4)$ & $1.11(0.96-1.29)$ & 0.15 & $172(12.8)$ & 1.00 & - & $318(23.8)$ & $1.68(1.39-2.02)$ & $<0.01$ \\
\hline No & $795(30.6)$ & 1.00 & - & $539(20.7)$ & $1.68(1.39-2.04)$ & $<0.01$ & $390(15.0)$ & 1.00 & - \\
\hline \multicolumn{10}{|l|}{ Need for treatment } \\
\hline Yes & $847(30.6)$ & $0.91(0.78-1.06)$ & 0.22 & $553(20.0)$ & $1.45(1.19-1.77)$ & $<0.01$ & $434(15.7)$ & $0.84(0.70-1.02)$ & 0.08 \\
\hline No & $408(34.8)$ & 1.00 & - & $158(13.4)$ & 1.00 & - & $274(23.4)$ & 1.00 & - \\
\hline \multicolumn{10}{|l|}{ Incentive to NSSI } \\
\hline Yes & $161(36.5)$ & $1.14(0.92,1.42)$ & 0.24 & $60(13.6)$ & $0.88(0.65-1.18)$ & 0.38 & $104(23.5)$ & $1.09(0.83-1.43)$ & 0.54 \\
\hline No & $1094(31.3)$ & 1.00 & - & $651(18.6)$ & 1.00 & - & $604(17.3)$ & 1.00 & - \\
\hline \multicolumn{10}{|l|}{ Mentions Method } \\
\hline Yes & $58(25.7)$ & 1.00 & - & $36(16.0)$ & 1.00 & - & $40(17.7)$ & 1.00 & - \\
\hline No & $1197(32.2)$ & $1.36(0.99-1.85)$ & 0.05 & $675(18.2)$ & $1.15(0.80-1.67)$ & 0.45 & $668(18.0)$ & $0.87(0.60-1.28)$ & 0.49 \\
\hline \multicolumn{10}{|l|}{$\begin{array}{l}\text { Expresses suicidal } \\
\text { behavior }\end{array}$} \\
\hline Yes & $82(41.8)$ & $1.47(1.09-1.97)$ & 0.01 & $45(22.9)$ & $1.46(1.03-2.06)$ & 0.03 & $55(28.0)$ & $1.59(1.10-2.28)$ & 0.01 \\
\hline No & $1173(31.4)$ & 1.00 & - & $666(17.8)$ & 1.00 & - & $653(17.4)$ & 1.00 & - \\
\hline
\end{tabular}

Source: Authors. 
The chance of expressing an individual suicidal behavior was increased in reply posts $(\mathrm{OR}=1.60 ; \mathrm{CI}=1.14-2.26 ; \mathrm{p}=$ $0.01)$ and with incentive to NSSI practice $(\mathrm{OR}=1.66 ; \mathrm{CI}=1.11-2.47 ; \mathrm{p}=0.01)$ (Data no show). First speech posts $(\mathrm{OR}=$ 3.09; $\mathrm{CI}=2.50-3.82 ; \mathrm{p}<0.01)$ or in which NSSI was not related to the need for treatment $(\mathrm{OR}=3.06 ; \mathrm{CI}=2.48-3.78 ; \mathrm{p}<0.01)$ had approximately three times the chance of encouraging NSSI. In addition, posts that did not mention methods $($ OR $=1.75$; $\mathrm{CI}=1.19-2.57 ; \mathrm{p}=0.01)$ and with an individual suicidal behavior $(\mathrm{OR}=1.75 ; \mathrm{CI}=1.17-2.61 ; \mathrm{p}<0.01)$ had almost twice the chance of expressing an incentive for NSSI (Table 3).

Table 3. Association of nonsuicidal self-injury incentive positioning and characteristics of posts $(\mathrm{n}=6,302)$ on Twitter $(2016-$ 2017).

\begin{tabular}{|c|c|c|c|c|c|c|}
\hline & \multicolumn{2}{|c|}{$\begin{array}{l}\text { Incentive to NSSI } \\
\text { Yes }(n=441)\end{array}$} & \multirow{2}{*}{$\begin{array}{c}\text { Adjusted } \\
\text { Odds } \\
\text { Ratio }\end{array}$} & \multirow{2}{*}{\multicolumn{2}{|c|}{ CI $95 \%$}} & \multirow[t]{2}{*}{ p-value } \\
\hline & $\mathbf{N}$ & $\%$ & & & & \\
\hline \multicolumn{7}{|l|}{ Gender } \\
\hline Female & 325 & 11.9 & 1.25 & 0.99 & 1.58 & 0.06 \\
\hline Male & 116 & 9.5 & 1.00 & - & - & - \\
\hline \multicolumn{7}{|c|}{ Post type } \\
\hline Reply & 94 & 14.0 & 1.14 & 0.88 & 1.47 & 0.32 \\
\hline Retweet & 8 & 10.5 & 1,06 & 0.49 & 2.29 & 0.88 \\
\hline Tweet & 339 & 10.6 & 1.00 & - & - & - \\
\hline \multicolumn{7}{|c|}{ First-person Speech } \\
\hline Yes & 274 & 20.5 & 3.09 & 2.50 & 3.82 & $<0.01$ \\
\hline No & 167 & 6.4 & 1.00 & - & - & - \\
\hline \multicolumn{7}{|c|}{ Need for treatment } \\
\hline Yes & 193 & 6.9 & 1.00 & - & - & - \\
\hline No & 248 & 21.1 & 3.06 & 2.48 & 3.78 & $<0.01$ \\
\hline \multicolumn{7}{|c|}{ Mentions Method } \\
\hline Yes & 38 & 16.8 & 1.75 & 1.19 & 2.57 & $<0.01$ \\
\hline No & 403 & 10.8 & 1.00 & - & - & - \\
\hline \multicolumn{7}{|c|}{$\begin{array}{l}\text { Expresses individual suicidal } \\
\text { behavior }\end{array}$} \\
\hline Yes & 35 & 17.8 & 1.75 & 1.17 & 2.61 & $<0.01$ \\
\hline No & 406 & 10.8 & 1.00 & - & - & - \\
\hline
\end{tabular}

Source: Authors.

The chance of mentioning the method was increased in posts with first-person speech $(\mathrm{OR}=1.41 ; \mathrm{CI}=1.06-1.87 ; \mathrm{p}=$ $0.02)$, which stimulated NSSI $(\mathrm{OR}=1.73 ; \mathrm{CI}=1.18-2.55 ; \mathrm{p}=0.01)$ and addressed the treatment need for NSSI $(\mathrm{OR}=1.53 ; \mathrm{CI}$ $=1.10-2.13 ; \mathrm{p}=0.01)$ and the chance of mentioning the method was decreased in reply posts $(\mathrm{OR}=0.64 ; \mathrm{CI}=0.42-0.97 ; \mathrm{p}=$ 0.04) (Table 4). 
Table 4. Mention of methods in nonsuicidal self-injury posts $(\mathrm{n}=6,302)$ on Twitter (2016-2017).

\begin{tabular}{|c|c|c|c|c|c|c|}
\hline & \multirow{2}{*}{\multicolumn{2}{|c|}{$\begin{array}{c}\begin{array}{c}\text { Method for } \\
\text { NSSI }\end{array} \\
\text { Yes (n= 225) }\end{array}$}} & \multirow{3}{*}{$\begin{array}{c}\text { Adjusted } \\
\text { Odds } \\
\text { Ratio }\end{array}$} & \multirow{2}{*}{\multicolumn{2}{|c|}{ CI 95\% }} & \multirow[t]{3}{*}{ p-value } \\
\hline & & & & & & \\
\hline & $\mathbf{N}$ & $\%$ & & & & \\
\hline \multicolumn{7}{|l|}{ Gender } \\
\hline Female & 169 & 6.2 & 1.31 & 0.96 & 1.78 & 0.10 \\
\hline Male & 56 & 4.6 & 1.00 & - & - & - \\
\hline \multicolumn{7}{|l|}{ Post type } \\
\hline Reply & 26 & 3.9 & 0.64 & 0.42 & 0.97 & 0.04 \\
\hline Retweet & 4 & 5.2 & 0.86 & 0.31 & 2.39 & 0.77 \\
\hline Tweet & 195 & 6.1 & 1.00 & - & - & - \\
\hline \multicolumn{7}{|c|}{ First-person Speech } \\
\hline Yes & 94 & 7.0 & 1.41 & 1,06 & 1.87 & 0.02 \\
\hline No & 131 & 5.0 & 1.00 & - & - & - \\
\hline \multicolumn{7}{|c|}{ Need for treatment } \\
\hline Yes & 171 & 6.1 & 1.53 & 1.10 & 2.13 & 0.01 \\
\hline No & 54 & 4.6 & 1.00 & - & - & - \\
\hline \multicolumn{7}{|c|}{ Incentive to NSSI } \\
\hline Yes & 38 & 8.6 & 1.73 & 1.18 & 2.55 & 0.01 \\
\hline No & 187 & 5.3 & 1.00 & - & - & - \\
\hline \multicolumn{7}{|c|}{ Expresses individual suicidal behavior } \\
\hline Yes & 7 & 3.5 & 0.58 & 0.27 & 1.24 & 0.16 \\
\hline No & 218 & 5.8 & 1.00 & - & - & - \\
\hline
\end{tabular}

Source: Authors.

\subsection{Analysis of qualitative data}

The qualitative analysis of posts encouraging non-suicidal self-injury on Twitter resulted in the construction of three main categories: "Manifestations of self-suicidal self-injury", "Social responses to self-suicidal behavior" and "Exposure to non-suicidal self-injury by mass communication".

\subsubsection{Manifestations of non-suicidal self-injury behavior}

This category presents tweets with perceptions of individuals about the practice of non-suicidal self-injury and the most common manifestations of behavior.

The category resource for difficult situations emphasizes the use of non-suicidal self-injury as a resource to alleviate emotional distress. It presents the need for understanding and support of close people and repulses judgment or punishment in the processes of identification and support of behavior. Alludes to the option of practitioners' confidentiality regarding the behavior and severity of recurrence of damage.

"At the age of 14 I couldn't handle anything and ran for the self-injury and bulimia practice; the worst is I didn't tell anyone this" (Mar-92)

"Solution I found to solve my problems. I need be respected and not be criticized" (Jul-224)

Intense desire signals the conflict between the negative representation of the act versus the frequent desire to selfinjure. It is highlighted the recurrence of desire, such as vicious behavior and the difficulty of dealing alone with the repeated manifestation of desire. 
"I have thought of self-mutilation more than 'normal'” (Oct-154)

"I can't deal with the thoughts I have all the time and my will to come back" (Mar-328)

On the other hand, romanticization presents a very positive understanding of non-suicidal self-injury and a sense of belonging to the repercussions of behavior that generate idealization and overvaluation of behavior. It is evidenced the existence of the possibility of understanding so positive that discourse can instigate practice and offer a sense of positive resource with behavior.

\author{
"Self-injury is the solution to any problem" (Mar-325) \\ "Self-injury is so cool, I recommend" (Jul-419) \\ "Self-injury is not for the weak" (May-170)
}

Mental disorders and risk behaviors (alcohol use and illicit drugs) appeared as simultaneous issues, triggering or resulting from non-suicidal self-injury, emphasizing the association with non-suicidal self-injury. It is highlighted the expression of belonging in relation to NSSI, mental disorders and risk behaviors as defining personal or group characteristics of the identity formation.

\author{
“Let's drink and self-injury” (Mar-245) \\ "I've had problems with feeding, bipolarity, self-injury and depression" (Nov-643)
}

Posts emphasized the non-suicidal and self-injury relationship and highlighted non-suicidal self-injury behavior as a "survival resource", being a behavior that can demonstrate the desire to stay alive and a resource to avoid the suicide. The fine line between non-suicidal self-injury behavior as a protective resource of suicide stands out, emphasizing that the behavior presents harm and damage, and the proximity of behavior with suicidal intentionality.

\footnotetext{
"Self-injury saved me from suicide many times" (Sep-27)

"We do it to survive and not to die" (Aug-476)

"I'm afraid of the moment that self-injury will stop being enough I can't be alone without thinking about suicide" (jun-20)

"Self-injury: alive from the outside, dead inside" (Dec-360)
}

\title{
3.2.2 Social responses to non-suicidal self-injury
}

Social responses were identified in different contexts related to non-suicidal self-injury.

The interest of non-suicidal self-injury practitioners in talking or linking with people with similar experience means the expectation of finding empathy or understanding of emotional pain or behavior primarily (or exclusively) in someone who experienced a similar situation.

\footnotetext{
"20-year-old girls who discount fending frustrations with self-injury, add me” (Jul-116)

"Anyone who has depression, anxiety, borderline, anorexia, suicidal tendencies, trauma, self-injury and mental illness in general are welcome" (Jan-168)
} 
Experiences without control and misunderstanding in the family context reveal family difficulties to deal with the situation and concern with the exposure of the problem, especially physical characteristics (cuts, scars) to other people, minimizing the need for attention to the suffering and reception of the individual. Some publications expressed "what the family should do" and the recommendations were varied, mainly including surveillance and punishments.

"My mom just worried if I'm going to cover or make up it in the summer so no one can see" (May-97)

"REQUIRE that the child to show his / her arms" (May-324)

About "helplessness and stigma in education", a feeling of frustration and revolt were identified about the verbalization of teachers reducing the behavior of NSSI. The trivialization of welcoming in the face of self-inflicted violence and mental disorders with automatic reproduction of simplistic discourses by teachers or school supervision. And the relationship with other students and the practice of jokes or expressions that disparage or reduce behavior and generate vexatious feelings in the school environment.

\footnotetext{
"The teacher began to ridicule depression" (Apr-343)

"The teacher defined it as 'wanting to draw attention'"
}

The experiences related to the lack of reception and professional bond were associated with feelings of ridicule, disrespect, lack of listening and individuality in care, and lack of preparation of professionals. These aspects impaired credibility in health care, and adherence to treatment.

"The two times I was hospitalized they laughed at me" (Nov-250)
"That's one of the patient's reasons not to talk, he doesn't feel comfortable" (Abr-431)

Religious institutions were conceived as spaces in which NSSI was poorly understood and prohibited and should be abandoned. In general, the posts pointed to faith as the only possible solution to solving problems and cessation of non-suicidal self-injury.

Believe, in the [religious institution group] you will find the solution (Nov-724)

"Self-mutilation does not solve your problems, but faith in the Living God yes" (Nov-679)

There was also the manifestation of social stigma and violence in the posts. Some contained explicit hate speech, and expressed that people with NSSI deserve to die and should resort to suicide.

"[NSSI] it's not serious stuff, it's freshness and lack of beating. Judge me". (Nov-293-3)

"In my opinion, you have to die! If you cut, dear, but, wait, cut the vein of the neck, then, plague..." (Dec-129-2)

\subsubsection{Exposure to non-suicidal self-injury by mass communication}

This category addresses the relationship between exposure to non-suicidal self-injury and violence self-inflicted by mass communication (Internet, audiovisual materials produced and reproduced on television channels, streaming platforms). 
The impact caused by audiovisual materials on NSSI was manifested by identifying the character characteristics, feelings of anguish highlighting the absence of later resources to deal with or mitigate the impact.

\footnotetext{
"Can this encourage self-injury / suicide and make victims feel more objectified by the media?” (Apr-816)

"They play some heavy themes (pedophilia, self-mutilation, rape) grotesquely and without exploiting right, shocks you but has no relief afterwards" (Apr-439)

"I saw at thirteen the first time, who presented me the self-mutilation, what I did until the 18" (Jul-56)
}

The relationship between virtual social networks and self-injury was ambiguous. Virtual social networks could foster support, peer access, reception of behavior, but also as a means of risk, with access to harmful information about behavior or incitement, romanticization of self-injury practice and other behaviors risk.

\footnotetext{
“The 10+ rules for using Twitter: 9- Use to assume other people's identity; 10-Encouraged self-injury” (Jun-125)

"Fanfic romanticizing bulimia, depression, self-injury, suicide, nothing new here” (Aug-455)

"What gave me "strength" was to see que I wasn't alone when I opened Tumblr" (Nov-192)
}

The difficulty of dealing with requests for help on the Internet expresses the feeling of frustration and the discomfort of not knowing how to proceed to offer help to people who practice NSSI and express their sufferings in virtual environments.
"I'm worried and wanted to send a message asking if she's okay" (Mar-115)
"Posting some self-injury stuff and I don't know what to do to help, dude" (Jun-65)

\section{Discussion}

Posts of female profiles prevailed, produced by the users themselves, without first-person speech, that is, without the expression of individuality or self-behavior. Prevailed posts met NSSI treatment needs and that did not contain some potentially harmful contents. The literature corroborates the predominance of female profiles. In research conducted with Taiwanese students, self-injurious behaviors with no suicidal intent were twice as high in girls(Tseng, Fang-Yi; Yang, 2015).

The minority of the posts expressed the author's suicidal behavior or NSSI encouragement. In the posts, the NSSI encouragement was linked to a greater chance of expressing a suicidal behavior, which in turn increased the chances for encouraging NSSI. Thus, it is possible for the vulnerable person (with suicidal behavior) to potentiate the vulnerability of others by identification (or contagion) or explicit encouragement to NSSI. Peer exposure or NSSI information is considered a strong risk factor for behavioral engagement(Fox, Millner, Mukerji, \& Nock, 2017; Jacob, Evans, \& Scour, 2017; Moreno et al., 2016).

The expression of individual suicidal behavior already poses a risk factor for the author of the post, in addition to potentiating risk for vulnerable users exposed to the content. Frost e Casey point out that young people seeking online support are associated with increased levels of suffering, NSSI episodes, and suicidal ideation, which ratifies the need for online posting monitoring(Frost, Casey, Frost, \& Casey, 2016).

First-person posts (indicative of individuality expression) in which NSSI was not linked to the need for treatment (possible naturalization or normalization) were more likely to encourage NSSI, a characteristic associated with the mention of NSSI methods. The most mentioned method in the posts was cutting, being the method most used and described in clinical and 
online research(Brown et al., 2018). Researchers emphasize users' concerns about normalizing behavior towards exposure to presentation or accessibility to methods and romanticizing the behavior(Moreno et al., 2016).

Evidenced that among the motivations for online interaction on NSSI was the need to seek and offer support and demystify the behavior(J. L. Whitlock, Powers, \& Eckenrode, 2006). However, in the present study, although replies to previous posts were less likely to mention methods, they were more likely to express suicidal behavior. The nature and consequences of these interactions between users with interests related to NSSI can be worrying. On the other hand, reply posts were more likely to engage users, as they were more liked and they had almost nine times the chances of being commented. Thus, it would be interesting to test mental health interventions that include responses to NSSI posts among its components.

The feeling of belonging and identification were highlighted in the study on non-suicidal self-injury in the virtual social network Instagram with concern for repercussion of identification, romanticization and appreciation of behavior through peer reactions(Moreno et al., 2016).

The posts also evidenced involvement with other risky behaviors, such as substance use (alcohol, illicit drugs) and body image distortion corroborating other studies(Hooley \& Franklin, 2018; Wang, Plöderl, Häusermann, \& Weiss, 2015). The NSSI was also linked to the use of avoiding suicide attempt, but with approach with suicidal ideation. Research points to NSSI as a risk factor for future suicidal behavior and highlights the possibility that previous NSSI history almost triples the chance of concomitant suicidal ideation(J. Whitlock \& Rodham, 2013; ).

Regarding social responses, the posts highlighted the search for peer empathy. However, research shows that people who knew someone with NSSI were more likely to report NSSI history(Kelada, Hasking, \& Melvin, 2016). The family context was associated with overlapping emotional distress by the family's social role. What ratifies the feeling of family absence by adolescents(Muehlenkamp \& Brausch, 2016). However, researchers highlight the family as an important point of reception, adolescent support and incentive of professional support(Kelada et al., 2016).

Professional support emerged in the posts and indicated stigma and commitment in adherence to treatment. People with NSSI stressed that nursing care is not based on their needs and stigmatized behaviors with negative repercussion in the NSSI itself predominate(Bosman \& Meijel, 2008). Another important support sector was also associated with trivializing behavior. The school context was pointed out by the underestimated and simplistic verbalization of teachers and relationship with other students. The importance of welcoming dissemination, focused and continuous support actions in the individual needs of NSSI practitioners and promoting healthy relationships between students as a protective factor(Madjar et al., 2017).

Religious institutions were present in the posts, but with stigmatized discourses, reduction of multicausality and uniqueness of religion as care to NSSI. Other Brazilian studies have identified the presence of religious institutions and NSSI content in virtual social networks and emphasize religiosity as a protective factor, but with the understanding of the complexity of the phenomenon and intersectoral support to NSSI(Costa, Silva, \& Vedana, 2019; Silva \& Botti, 2017).

The posts also reinforced society's judgment, including the presence of hate speech. Social stigma has a direct impact on NSSI and support, the results highlight the importance of disseminating responsible information and broad destigmatization in society. With regard to exposure mass communication vehicles, the posts presented the production of materials and potential to reinforce the process of identification and vulnerability in NSSI. Researchers point out that a person's behavior influences and is influenced by the social environment, and peer exposure and media can ease expectations of self-injury behavior(Hasking \& Rose, 2016; Kelada et al., 2016). It is important to understand that the media is not an isolated factor, but reduced self-efficacy and media exposure over NSSI is associated with increased probability for behavior(Kelada et al., 2016).

The relationship of virtual social networks was present in the posts in a dichotomous way. Other national and international researches ratify the complexity of the virtual environment related to self-inflicted behaviors(Costa et al., 2019). 
A study conducted with young people points out that most young people report greater availability in online support and greater possibility of seeking online support for support from friends or family. However, the same study points out that people seeking help on the Internet are mostly younger, have more negative feelings and high level of harmful behavior(Frost et al., 2016).

An important finding was linked to feelings and repercussions in people who identify a request for help on the Internet. Researches indicate that today's generations are more integrated and that the Internet enables this better integration. However, professionals warn about the complexity of youth responsibility by responding to someone at risk of selfviolence(Hetrick et al., 2018). Thus, it is highlighted the need to deepen research, debates and the production of materials and tools for the care of self-inflicted violence in a virtual environment.

The analysis of the posts was performed alone, and it was not possible to verify the relationship between tweet or retweet and replies, an aspect that can be incorporated in further studies. Another important limitation was related to the transverse collection without a longitudinal follow up of the posts of each user.

\section{Conclusion}

In the present study, they were investigated as posts on the NSSI on Twitter. Female profile posts, produced by users, with no potentially harmful content predominated. The results contributed to the understanding of the characteristics of nonsuicidal automation of the virtual environment and the possibility of reflecting on the findings for behavioral care in the online and offline context. The understanding of non-suicidal automation as a dependent behavior that requires focused and continuous actions on the individual's needs is highlighted.

Understanding the potential of this type of research and translation of knowledge for reflection on the health-disease process and the possibilities of health promotion actions is a necessity in the current global context. These results are important for the understanding of the phenomenon, the development of preventive actions and the planning of monitoring adolescents with NSSI.

We emphasize the transience of information on the internet as an important limitation and the need for future studies with integrated and specific analyzes of virtual social networks as a contribution to understanding the theme in the virtual environment. We also highlight the need for studies on health information on non-suicidal self-harm and the translation of this knowledge into action and preventive health actions.

\section{Acknowledgments}

This study was financed in part by the Coordenação de Aperfeiçoamento de Pessoal de Nível Superior - Brasil (CAPES) - Finance Code 001

\section{References}

American Psychiatric Association. (2013). Diagnostic and Statistical Manual of Mental Disorders. Arlington.

Bosman, M., \& Meijel, B. Van. (2008). Perspectives of Mental Health Professionals and Patients on Self-Injury in Psychiatry: A Literature Review. 180 Archives OfPsychiatric Nursing, 22(4), 180-189. https://doi.org/10.1016/j.apnu.2007.07.006

Braun, V. \& Clarke, V. (2006). Thematic_Analysis_Revised_-_Final. Qualitative Research in Psychology, 3((2)), 77-101. https://doi.org/10.1191/1478088706qp063oa

Braun, V., \& Clarke, V. (2006). Using thematic analysis in psychology. Qualitative Research in Psychology, 3(2), 77-101. https://doi.org/10.1191/1478088706qp063oa 
Brown, R. C., Fischer, T., Goldwich, A. D., Keller, F., Young, R., \& Plener, P. L. (2018). \# cutting : Non-suicidal self-injury ( NSSI ) on Instagram. Psychological Medicine, 48(2), 337-346. https://doi.org/10.1017/S0033291717001751

Cassel, P. A., Terribile, T. G. \& Machado, J. C. (2019). Por trás da tela: uso e consequências dos jogos online para multijogadores. Research, Society and Development, 8(10):e-498101421. https://doi.org/10.33448/rsd-v8i10.1421

Costa, J. dos S., Silva, A. C., \& Vedana, K. G. G. (2019). Postagens sobre autolesão não suicida na internet. Adolescencia \& Saúde, 16(1), 7-12.

Fox, K. R., Millner, A. J., Mukerji, C. E., \& Nock, M. K. (2017). Examining the role of sex in self-injurious thoughts and behaviors. Clinical Psychology Review, (June), 0-1. https://doi.org/10.1016/j.cpr.2017.09.009

Frost, M., Casey, L., Frost, M., \& Casey, L. (2016). Who Seeks Help Online for Self-Injury? Who Seeks Help Online for. USUI, 20(1), 69-79. https://doi.org/10.1080/13811118.2015.1004470

Vedana, K. G. G., Donato, G. D. I., Miasso, A. I., Carolina, A. N. A., Zanetti, G., \& Borges, T. L. (2018). Most popular posts about suicide in blogs Postagens mais populares sobre suicídio em blogs. Pensar Enfermagem, 22(1), 61-74.

Vedana, K. G. G., Silva, A. F., Corrêa, C., Pereira, M., \& Silva, G. L. (2018). Blue Whale": blog posts about the suicide game. J Contemp Nurs, 7(1), 1-7. https://doi.org/10.17267/2317-3378rec.v7i1.1736

Hasking, P., \& Rose, A. (2016). A Preliminary Application of Social Cognitive Theory to Nonsuicidal Self-Injury. Journal of Youth and Adolescence, 45(8), 1560-1574. https://doi.org/10.1007/s10964-016-0449-7

Hetrick, S. E., Robinson, J., Burge, E., Blandon, R., Mobilio, B., Rice, S. M., \& Davey, C. G. (2018). Youth codesign of a mobile phone app to facilitate selfmonitoring and management of mood symptoms in young eople with major depression, suicidal ideation, and self-harm. Journal of Medical Internet Research, 20(1), 1-19. https://doi.org/10.2196/mental.9041

Hooley, J. M., \& Franklin, J. C. (2018). Why Do People Hurt Themselves? A New Conceptual Model of Nonsuicidal. https://doi.org/10.1177/2167702617745641

Jacob, N., Evans, R., \& Scour, J. (2017). The in fl uence of online images on self-harm : A qualitative study of young people aged 16 e $24,60,140-147$. https://doi.org/10.1016/j.adolescence.2017.08.001

Kelada, L., Hasking, P., \& Melvin, G. A. (2016). The Relationship Between Nonsuicidal Self-Injury and Family Functioning: Adolescent and Parent Perspectives. Journal of Marital and Family Therapy, 80(8), 1056-1077. https://doi.org/10.1111/jmft.12150

Lewis, S. P., Heath, N. L., Michal, N. J., \& Duggan, J. M. (2012). Non-suicidal self-injury, youth , and the Internet: What mental health professionals need to know. Child and Adolescent Psychiatry and Mental Health, 6(1), 1. https://doi.org/10.1186/1753-2000-6-13

Lim, K., Wong, C. H., Mcintyre, R. S., Wang, J., Zhang, Z., Tran, B. X., \& Ho, R. C. (2019). Global Lifetime and 12-Month Prevalence of Suicidal Behavior , Deliberate Self-Harm and Non-Suicidal Self-Injury in Children and Adolescents between 1989 and 2018: A Meta-Analysis. International Journal of Environmental Research and Public Health, 16(22), 4581.

Madjar, N., Shabat, S. Ben, Elia, R., Fellner, N., Rehavi, M., Rubin, S. E., \& Shoval, G. (2017). Non-suicidal self-injury within the school context : Multilevel analysis of teachers' support and peer climate. European Psychiatry, 41, 95-101. https://doi.org/10.1016/j.eurpsy.2016.11.003

Marchant, A., Hawton, K., Stewart, A., Montgomery, P., Singaravelu, V., Lloyd, K., \& John, A. (2017). A systematic review of the relationship between internet use, self-harm and suicidal behaviour in young people: The good, the bad and the unknown. PloS One, 12(8), e0181722. https://doi.org/10.1371/journal.pone.0181722

Ministério da Saúde. (2012). Resolução no 466, de 12 DE Dezembro de 2012.

Moreno, M. A., Ed, M. S., H, M. P., Ton, A., Selkie, E., H, M. P. (2016). Secret Society 123 : Understanding the Language of Self-Harm on Instagram. Journal of Adolescent Health, 58(1), 78-84. https://doi.org/10.1016/j.jadohealth.2015.09.015

Muehlenkamp, J. J., \& Brausch, A. M. (2016). Reconsidering Criterion A for the Diagnosis of Non-Suicidal Self-Injury Disorder. Journal of Psychopathology and Behavioral Assessment, 547-558. https://doi.org/10.1007/s10862-016-9543-0

Pereira, A. S. et. al (2018). Metodologia da pesquisa científica UFSM. https://repositorio.ufsm.br/bitstream/handle/1/15824/Lic_Computacao_MetodologiaPesquisa-Cientifica.pdf?sequence $=1$

Silva, A. C., \& Botti, N. C. L. (2017). Compreensão das Postagens de um grupo de automutilação no Facebook a partir do modelo de prevenção de recaídas de Marlatt. https://doi.org/978-85-62707-97-1

Tseng, F.-Y.; \& Yang, H.-J. (2015). Internet Use and Web Communication Networks, Sources of Social Support , and Forms of Suicidal and Nonsuicidal Self-Injury Among Adolescents: Different Patterns Between Genders. Suicide \& Life-Threatening Behavior, 45(110), 178-191. https://doi.org/10.1111/sltb.12124

Vedana, K. G. G., Pereira, C. C. M., Di Donato, G., \& Vanzela, A. S. (2018). "13 Reasons Why": social blog posts about the book and series related to suicidal behavior among young individuals. Enfermagem Revista, 21(1), 2-10.

Wang, J., Plöderl, M., Häusermann, M., \& Weiss, M. G. (2015). Understanding Suicide Attempts Among Gay Men From Their Self-perceived Causes. The Journal of Nervous and Mental Disease, 203(7), 499-506. https://doi.org/10.1097/NMD.0000000000000319

Whitlock, J. L., Powers, J. L., \& Eckenrode, J. (2006). The virtual cutting edge: The Internet and adolescent self-injury. Developmental Psychology, 42(3), 
Research, Society and Development, v. 10, n. 4, e40410413017, 2021

(CC BY 4.0) | ISSN 2525-3409 | DOI: http://dx.doi.org/10.33448/rsd-v10i4.13017

407-417. https://doi.org/10.1037/0012-1649.42.3.407

Whitlock, J., \& Rodham, K. (2013). School Psychology Forum : Understanding Nonsuicidal Self-Injury in Youth, 7(4), 93-110. 